INTERNATIONAL JOURNAL OF ENVIRONMENT

Volume-3, Issue-3, Jun-Aug 2014

ISSN 2091-2854

Received: 19 May

Revised:2 June

Accepted:20 August

\title{
GENETIC VARIATION OF GROUNDNUT (Arachis hypogaea L.) GENOTYPES IN SEMI-ARID ZONE SUDAN
}

\author{
Salih A. I. Sabiel ${ }^{1 *}$, Mohamed I. Ismail ${ }^{2}$, Elgailani Abdalla ${ }^{3}$ and Khalid A. Osman ${ }^{4}$ \\ 1,2,3,4 Plant Breeding Program, Agricultural Research Corporation, Wad Medani, P. O. Box 126, \\ Sudan \\ *Corresponding author: saibeel@yahoo.com
}

\begin{abstract}
Twelve genotypes of groundnut (Arachis hypogaea L.) were executed under rain-fed conditions in a semi-arid zone at the Research farm of El Fasher Research Station, Sudan for two consecutive seasons 2006 and 2007. Genotypic and phenotypic variability, heritability in a broad sense and genetic advance were estimated in a randomized complete block design with four replications. High heritability estimate (above $95 \%$ ) was recorded by hay yield (kg/ha) in both seasons and 100- seed weight in season 2006. Moreover, the high genetic advance was recorded for hay yield $(\mathrm{kg} / \mathrm{ha})$ and pod yield $(\mathrm{kg} / \mathrm{ha})$ in both seasons. However, a day to $50 \%$ flowering was expressed low genotypic coefficient of variation with low genetic advances in both seasons. Highly significant different among genotypes were found for days to $50 \%$ flowering, hay yield $(\mathrm{kg} / \mathrm{ha})$, shelling $(\%)$, while pod yield $(\mathrm{kg} / \mathrm{ha})$ and $100-$ seed weight were observed nonsignificant. The high yielding genotype was ICGV93260 with a pod yield of $1389.1 \mathrm{~kg} / \mathrm{ha}$. Pod yield ( $\mathrm{kg} / \mathrm{ha}$ ) was highly significantly and positively correlated with hay yield $(\mathrm{kg} / \mathrm{ha})$, shelling $(\%)$ and 100- seed weight, while non-significant and negative correlated with days to $50 \%$ flowering. Based on the results the characters hay yield $(\mathrm{kg} / \mathrm{ha})$, shelling $(\%), 100$ - seed weight and days to $50 \%$ flowering to be the important characters which would be used in selection for groundnut improvement. The promising genotype identified in this study could provide valuable sources of resistance to climate-change-related stresses and for other consequent breeding activities in groundnut improvement.

Key words: Groundnut, genetic, variability, heritability, correlation
\end{abstract}




\section{Introduction}

Groundnut (Arachis hypogaea L.) is annual legume allotetraploid species with $2 \mathrm{n}=40$ (Dwivedi et al., 2001) widely cultivated under rain-fed conditions in arid and semi-arid regions of the world (Thakur et al., 2013). It is an important crop used for a source of food, edible oil, feed, digestable proteins, vitamins, minerals, phytosterols, fuel, cosmetics and green manuring crop for improvement of soil validity (Reddy et al., 2003; Ronghua et al., 2007; Shoba et al., 2010; Sudhir et al., 2010; Zaman et al., 2011). Reduced of rainfall over various regions and there is a strong fluctuation from year to year results decreased in yield of crops (Bhandari, 2014). Groundnut is sensitive to drought stress during the all growing stages; cause the greatest reduction in yield and quality (Gowda et al., 2009; Prathima et al., 2011; Ramesh et al., 2007).

Sudan is one of most an important countries producer groundnut in the world (Zaman et al., 2010). It is a major oilseed and cash crop, used for food, forage and the enhancement of soil fertility. The majority of groundnut crop cultivated under rain-fed conditions and sandy soil, it has been reduced due to severely affected by drought stress and depending on traditional subsistent farming systems (Fadl and Gebauer, 2004). Several studies on groundnut have been carried out, but has a few attentions and there is limited information regarding its genetics, breeding and production, especially genetic improvement under rain-fed conditions, due to groundnut has a narrow genetic base due to its monophyletic origin, self-pollination and lack of gene flow (Meta and Monpara, 2010). Moreover, to improve and sustain the yield of groundnut under rain-fed condition, plant breeders should have a better understanding of the genetic variability of yield and its components and development of high yielding cultivars with drought tolerant at different stages of crop growth (Reddy et al., 2003; Zaman et al., 2010). Therefore, the objectives of this study were to estimate the genotypic and phenotypic variability, broad sense heritability, morphological and yield associated traits of groundnut genotypes under rain-fed conditions in the semi-arid region of Sudan. The result of this investigation may provide good information for advance understanding of genetic variability, suitable selection criteria for predicting the pod yield in groundnut and further breeding program.

\section{Materials and Methods}

\section{Study site and experimental design}

The experiment was conducted under rain-fed conditions in a semi-arid zone at El Fasher Research Station Farm located on $\left(13^{\circ} 37^{\prime} \mathrm{N} 25^{\circ} 20^{\prime} \mathrm{E}, 748 \mathrm{msl}\right)$ North Darfur State, Western Sudan, in sandy soil without fertilizer, non-pesticide nor irrigation for two consecutive cropping seasons 2006 and 2007. The total amount of rainfall received during the growing season was 256 and $278.1 \mathrm{~mm}$ for 2006 and 2007, respectively (Table 1). Twelve genotypes of groundnut (Arachis hypogaea L.) were used for the study, obtained from the national program, Agricultural Research Corporation, Sudan. These genotypes were ICG221, ICGV92121, ICGV92126, ICGV86744, ICGV93955, ICGV89171, ICGV89104, ICGV93260, ICGV93261, ICGV93269, SODIRI and BARBERTON. The experiment was planted on the 9 July 2006 and 13 July 2007. The study was laid out in a Randomized Complete Block Design (RCBD) with 
four replications. Each genotype was planted in 5 rows of 4 meter length, with spacing of $60 \mathrm{~cm}$ between rows and $20 \mathrm{~cm}$ between plant holes. The total plot size was $12 \mathrm{~m}^{2}$ the net harvested plot size was $6.48 \mathrm{~m}^{2}$ (3middle rows of 3.6 meters length). Three to four seeds were planted in each hole and seedlings were thinned to two plants per hole, two weeks after planting. Each row contained 20 plants. Weeding was performed by hand two times per season.

Table 1. Monthly and seasonal rainfall during growing season of 2006 and 2007 at El Fasher Research Station in North Darfur, Sudan

\begin{tabular}{lll}
\hline Month & Season 2006 & Season 2007 \\
\hline April & - & - \\
May & - & 13.5 \\
June & 6.0 & - \\
July & 68 & 42.9 \\
August & 122.8 & 207.5 \\
September & 59.2 & 14.2 \\
\hline Total annual rainfall & $256 \mathrm{~mm}$ & $278.1 \mathrm{~mm}$ \\
\hline
\end{tabular}

\section{Data collection}

Data were recorded on days to $50 \%$ flowering (days from sowing to a time when $50 \%$ of the plants start to flower), 100 seed weight $(\mathrm{g})$, shelling $(\%)$, hay yield $(\mathrm{kg} / \mathrm{ha})$ and pod yield (kg/ha).

\section{Statistical analysis}

Analysis of variance (ANOVA) was carried out on the data to assess the genotypic effects and their interaction using a general linear model (GLM) procedure for randomized complete block design in SAS (version 8). Based on the analysis of variance, phenotypic and genotypic variances, heritability, genotypic coefficient of variation, genetic advance and phenotypic correlation between pod yield and traits were estimated. Means for each season and two seasons were used to compute simple linear correlation coefficients.

\section{Results and Discussion}

The results showed highly significant variation among the genotypes for most of the trait studies in both seasons (Table 2), a similar conclusion was reported by Thakur et al. (2013); Zaman et al. (2011). They had suggested that selection based on these characters will be meaningful in predicting for pod yield in groundnut. The high genotypic coefficient of variation and genetic advance were recorded for pod yield (kg/ha) in both seasons (Table 2). High heritability estimate (above $95 \%$ ) was recorded by hay yield (kg/ha) in both seasons and 100seed weight in season 2006. This finding is in agreement with the results obtained by Ayub Khan et al. (2000); Meta and Monpara (2010), indicting participation of additive gene action for these traits. Moreover, the high genetic advance was recorded for hay yield $(\mathrm{kg} / \mathrm{ha})$ and pod yield 
( $\mathrm{kg} / \mathrm{ha})$ in both seasons, have been also reported in previous studies by Golakia et al. (2005); Parmeshwarappa et al. (2008); Venkateswarlu et al. (2007), indicating that this character was under the control of additive genetic effects. However, days to $50 \%$ flowering were expressed low genotypic coefficient of variation with low genetic advances in both seasons (Table 2). They suggested that the trait is less an expression of environmental influence.

Table2. Estimates of heritability in the broad sense $\left(h^{2} B\right),(G C V)$ and (PCV) coefficients of variation, genetic advance (GA) as a percentage of the mean for 5 traits in 12 Groundnut grown at the FRS, seasons 2006 and 2007

\begin{tabular}{lclcccccc}
\hline Traits & Seasons & Range & Means & F value & $\mathrm{H}^{2} \mathrm{~B}$ & $\mathrm{GCV}$ & $\mathrm{PCV}$ & $\mathrm{GA}$ \\
\hline Pod yield (kg/ha) & 2006 & $1244-943$ & 1066.75 & $9.24^{* * *}$ & 90.2 & 9.8 & 10.3 & 92.7 \\
& 2007 & $1643-1266$ & 1501.08 & $1.13^{\mathrm{ns}}$ & 53 & 8.22 & 11.29 & 85.2 \\
Days to 50\% flowering & 2006 & $37-36$ & 36.35 & $4.57^{* * *}$ & 82.1 & 1.5 & 1.7 & 1.04 \\
& 2007 & $37-34$ & 35.27 & $3.08^{* *}$ & 75.5 & 2.21 & 2.54 & 1.4 \\
\multirow{3}{*}{ 100- seed weight (g) } & 2006 & $32.0-26.8$ & 28.96 & $53.97^{* * *}$ & 98 & 6.27 & 6.34 & 3.7 \\
& 2007 & $37.0-28.8$ & 33.81 & $2.39^{*}$ & 50.5 & 6.3 & 8.92 & 3.11 \\
Shelling (\%) & 2006 & $73.1-66.1$ & 70.17 & $2.57^{*}$ & 72 & 2.91 & 3.43 & 3.56 \\
& 2007 & $75.6-69.5$ & 72.49 & $2.20^{*}$ & 68.8 & 2.05 & 2.48 & 2.54 \\
Hay yield (kg/ha) & 2006 & $2556-2136$ & 2291.54 & $38.0^{* * *}$ & 97.4 & 5.71 & 5.8 & 93.1 \\
& 2007 & $4586-3269$ & 3892.44 & $40.07^{* * *}$ & 97.6 & 9.67 & 9.79 & 96 \\
\hline
\end{tabular}

$*, * *, * * *$ Significant at $0.05,0.01$ and 0.001 probability level, respectively

The combined analysis showed that the genotypes were differed highly significantly for hay yield (kg/ha), shelling (\%) and days to 50\% flowering (Table 3). Similar patterns of variability also reported by Zaman et al. (2011). While non-significant for pod yield (kg/ha) and 100- seed weight was observed (Table 3). The early flowering genotypes were ICGV93261 and ICGV93269 however; the late flowering genotype was BARBERTON. The high yielding genotype was ICGV93260 with a pod yield of $1389.1 \mathrm{~kg} / \mathrm{ha}$ (Table 3). The promising genotype identified in this study could provide valuable sources of resistance to climate-change-related stresses and for other consequent breeding activities in groundnut improvement. 
Table 3. Mean performance of 12 Groundnut genotypes grown at the FRS Farm (combined over two seasons, 2006 and 2007)

\begin{tabular}{llllll}
\hline Genotypes & PY & DF & SW & SH & HY \\
\hline ICG221 & $1290.9 \mathrm{ab}$ & $36.0 \mathrm{abcde}$ & $31.4 \mathrm{ab}$ & $72.0 \mathrm{ab}$ & $3035.3 \mathrm{~d}$ \\
ICGV92121 & $1138.1 \mathrm{~b}$ & $35.3 \mathrm{de}$ & $32.3 \mathrm{ab}$ & $69.6 \mathrm{bc}$ & $2831.3 \mathrm{e}$ \\
ICGV92126 & $1280.9 \mathrm{ab}$ & $36.2 \mathrm{abcd}$ & $29.9 \mathrm{~b}$ & $69.0 \mathrm{c}$ & $3451.3 \mathrm{a}$ \\
ICGV86744 & $1188.3 \mathrm{ab}$ & $36.4 \mathrm{ab}$ & $31.4 \mathrm{ab}$ & $70.6 \mathrm{abc}$ & $2738.6 \mathrm{f}$ \\
ICGV93955 & $1224.3 \mathrm{ab}$ & $35.6 \mathrm{bcde}$ & $31.5 \mathrm{ab}$ & $72.0 \mathrm{ab}$ & $3036.8 \mathrm{~d}$ \\
ICGV89171 & $1272.3 \mathrm{ab}$ & $35.4 \mathrm{cde}$ & $33.1 \mathrm{a}$ & $70.9 \mathrm{abc}$ & $3231.3 \mathrm{~b}$ \\
ICGV89104 & $1235.5 \mathrm{ab}$ & $35.4 \mathrm{cde}$ & $31.0 \mathrm{ab}$ & $71.2 \mathrm{abc}$ & $3197.8 \mathrm{bc}$ \\
ICGV93260 & $1389.1 \mathrm{a}$ & $36.5 \mathrm{ab}$ & $31.0 \mathrm{ab}$ & $69.2 \mathrm{bc}$ & $3377.0 \mathrm{a}$ \\
ICGV93261 & $1360.0 \mathrm{ab}$ & $35.1 \mathrm{e}$ & $31.8 \mathrm{ab}$ & $73.0 \mathrm{a}$ & $3040.0 \mathrm{~d}$ \\
ICGV93269 & $1351.4 \mathrm{ab}$ & $35.1 \mathrm{e}$ & $30.4 \mathrm{ab}$ & $72.9 \mathrm{a}$ & $3150.6 \mathrm{bc}$ \\
SODIRI & $1316.4 \mathrm{ab}$ & $36.3 \mathrm{abc}$ & $31.0 \mathrm{ab}$ & $72.7 \mathrm{a}$ & $3112.9 \mathrm{~cd}$ \\
BARBERTON & $1360.0 \mathrm{ab}$ & $36.6 \mathrm{a}$ & $33.1 \mathrm{a}$ & $73.0 \mathrm{a}$ & $2901.3 \mathrm{e}$ \\
CV\% & 15.8 & 2.4 & 7.7 & 3.5 & 2.9 \\
SE & 25.9 & 0.2 & 0.6 & 0.6 & 22.3 \\
Pr>F & $1.13 \mathrm{~ns}$ & $3.4 * * *$ & $1.0 \mathrm{~ns}$ & $2.9 * *$ & $44.3 * * *$ \\
\hline
\end{tabular}

$*, * *, * * *$ Significant at $0.05,0.01$ and 0.001 probability level, respectively

Means followed by the same letter(s) within a column are not significantly different at 0.05 probability level According to LSD test. PY: Pod yield (kg/ha); DF: Days to $50 \%$ flowering; SW: 100 grain weight (g); SH: Shelling (\%); HY: Hay yield (kg/ha).

These results exposed that the pod yield was positively correlated and highly significantly associated with hay yield $\mathrm{kg} / \mathrm{ha}(\mathrm{r}=0.76), 100$ - seed weight $(\mathrm{r}=0.62)$ and shelling $\%(\mathrm{r}=0.51)$ and confirmed those previously recorded by Ayub Khan et al. (2000); Meta and Monpara (2010) in groundnut, and Shegro et al. (2013) in Bambara groundnut, suggests that selection on the basis of the phenotypic of these characters will lead to high pod yield in groundnut. However, negative and non-significant association between pod yield $(\mathrm{kg} / \mathrm{ha})$ and days to $50 \%$ flowering $(\mathrm{r}=-0.12)$ was exhibited (Table 4). This finding is in agreement with reported by Ibrahim et al. (2013) in Guar; Meta and Monpara (2010) in groundnut. Indicated that late flowering plants would tend to produce more pod yield and selection based on days to $50 \%$ flowering alone will be depressing pod yield in groundnut. The results from this study lead to the hay yield ( $\mathrm{kg} / \mathrm{ha})$, shelling (\%), 100 - seed weight and days to $50 \%$ flowering should be considered during selection for pod yield in groundnut. Therefore, suggested that it may be the important characters selection for the improvement of the pod yield in groundnut. 
Table 4. Simple linear correlation coefficients between 5 pairs of traits in Groundnut at the FRS Farm (combined over two seasons, 2006 and 2007)

\begin{tabular}{cccccc}
\hline Traits & PY & DF & SW & SH & H Y \\
\hline PY & 1 & -0.122 & $0.622 * * *$ & $0.513 * * *$ & $0.755^{* * *}$ \\
DF & -0.122 & 1 & $-0.225^{*}$ & -0.045 & $-0.414 * * *$ \\
SW & $0.622^{* * *}$ & $-0.225 *$ & 1 & $0.438 * * *$ & $0.542 * * *$ \\
SH & $0.513 * * *$ & -0.045 & $0.438 * * *$ & 1 & $0.348 * * *$ \\
HY & $0.755^{* * *}$ & $-0.414 * * *$ & $0.542 * * *$ & $0.348 * * *$ & 1 \\
\hline
\end{tabular}

$*, * *, * * *$ Significant at $0.05,0.01$ and 0.001 probability level, respectively

PY: Pod yield (kg/ha); DF: Days to 50\% flowering; SW: 100 grain weight (g); SH: Shelling (\%); HY: Hay yield (kg/ha).

\section{Conclusion}

It could be concluded from this study that there is adequate genetic variability present in the material studied. In the broad sense heritability, genetic advance and correlation among traits found that the selection for hay yield (kg/ha), shelling (\%), days to $50 \%$ flowering and 100 - seed weight would be more effective traits in boosting pod yield performance of groundnut genotypes. Among the evaluated, the high yielding genotype was ICGV93260 with a pod yield of 1389.1 $\mathrm{kg} / \mathrm{ha}$, and has the greatest potential to adapt in semi-arid region, climatic conditions and to enhance groundnut production under rain-fed condition in the Western Sudan, and for other consequent breeding activities in groundnut improvement.

\section{Acknowledgement}

We gratefully acknowledge the El Fasher Research Station staff for their assistance during the fieldwork. The study was funded by the Agricultural Research Corporation (ARC) Sudan.

\section{References}

Ayub Khan, M. R., Idrees Khan, M., Tahir, 2000. Genetic variability and criterion for the selection of high yielding peanut genotypes. Pakistan J. Agric. Res. Vol. 16, No. 1.

Bhandari, G., 2014. Effect of rainfall on the yield of major cereal in Darchula District of Nepal. 3 (1): 205-213.

Dwivedi, S. L., Gurtu, S., Chandra, S., Yuejin, W., Nigam, 2001. Assessment of genetic diversity among selected groundnut germplasm. I: RAPD analysis. Plant Breeding. 120: 345-349.

Fadl, K. E. M., Gebauer J., 2004. Crop performance and yield of groundnut, sesame and roselle in an agroforesty cropping system with Acacia Senegal in North Kord-ofan (Sudan). Journal of Agriculture and Rural Development in the Tropics and Subtropics. 105(2):149-154. 
Golakia, P. R., Makne, V. G., Monpara, B. A., 2005. Heritable variation and association in Virginia and Spanish bunch group of groundnut. National Journal of Plant Improvement. 7:50-53.

Gowda, C. L. L., Serraj, R., Srinivasan, G., Chauhan, Y. S., Reddy, B. V. S., Rai, K. N., Nigam, S. N., Gaur, P. M., Reddy, L. J., Dwivedi, S. L., Upadhyaya, H. D., Zaidi, P. H., Rai, H. K., Maniselvan, P., Follkerstma, R., Nalini, M., 2009. Opportunities for improving crop water productivity through genetic enhancement of dryland crops. CAB International, 2009. Rainfed Agriculture: Unlocking the Potential.

Ibrahim, E. A., Abdalla A. H., Abdel Rahman, M. E., 2013. Genotypic and phenotypic correlations between yield and yield components in some guar (Cyamopsis tetragonoloba L.) genotypes under rainfed condition. Afr. J. Agric. Res. 8 (18):18641871.

Meta, H.R., Monpara, B.A., 2010. Genetic variation and trait relationships in summer groundnut, (Arachis hypogaea L.). J. Oilseeds Res. 26:186-187.

Parmeshwarappa, K.G., Malabasari, T. A., Lingaraju, B. S., 2008. Analysis of correlations and path effects among yield attributing traits in two crosses of large seeded groundnut, Arachis hypogaea L. Journal of Oilseeds Research. 25:4-7.

Prathima, T., Yellamanda Reddy, T., Murali Krishna, T., Devaki, K., Sudhakar, P., Sarala, N. V., Muneendra Babu, A., Naga Madhuri, K. V., 2011. Validation of pnutgro model for moisture stress effects on rainfed groundnut in major crop growing areas of Andhra Pradesh, India- A critical review. International Journal of Applied Biology and Pharmaceutical Technology. 2(4) 482-509.

Ramesh, K., Sheikh, M., Hemanth, K. N. V., Naik K. S. S., 2007. Identification of drought tolerant groundnut genotypes employing proteomics approach. An Open Access Journal published by ICRISAT, December 2007, Volume 5. Issue 1.

Reddy, T. Y., Reddy, V. R., Anbumozhi, V., 2003. Physiological responses of groundnut (Arachis hypogeal L.) to drought stress and its amelioration: a critical review. Plant Growth Regulation. 41: 75-88.

Ronghua, T., Guoqing, G., Liangqiong, H., Zhuqiang, H., Shihua, S., Ruichun, Z., Cuiqiu, Z., Jing, J., Yangrui, L., Weijian, Z., 2007. Genetic diversity in cultivated groundnut based on SSR Markers. Journal of Genetics and Genomics. 34 (5): 449-459.

Shegro, A., Jansen van Rensburg, W. S., Adebola, P. O., 2013. Assessment of genetic variability in Bambara groundnut (Vigna subterranean L. Verdc.) using morphological quantitative traits. Acad. J. Agric. Res. 1(3): 045-051.

Shoba, D., Manivannan, N., Vindhiyavarman, P., 2010. Genetic diversity analysis of groundnut genotypes using SSR markers. Electronic Journal of Plant Breeding. 1(6): 1420-1425.

Sudhir, I. K., Govindaraj, M., Vijay K. K., 2010. Estimation of genetic diversity of new advanced breeding lines of groundnut (Arachis hypogeal L.). World journal of agricultural sciences. 6 (5): 547-554. 
Thakur, S. B., Ghimire, S. K., Shrestha, S. M., Chaudhary, N. K., Mishra, B., 2013. Variability in Groundnut Genotypes for Tolerance to Drought. Nepal Journal of Science and Technology. Vol. 14 (1): 41-50.

Venkateswarlu, O., Raja Reddy, K., Reddy, P. V., Vasanthi, R. P., Hari Prasad Reddy, K., Eswara Reddy, N. P., 2007. Character association and path analysis for morphophysiological traits in groundnut, Arachis hypogaea L. Journal of Oilseeds Research. 24:20-22.

Zaman, M. A., Tuhina-Khatun, M., Ullah, M. Z., Moniruzzamn, M., Alam, K. H., 2011. Genetic variability and path analysis of groundnut (Arachis hypogaea L.). The Agriculturists. 9 (1\&2): 29-36.

Zaman, M. A., Tuhina-Khatun, M., Bhuiyan, M. M. H., Moniruzzamn, M., Yousu, M. N., 2010. Genetic divergence in groundnut (Arachis hypogaea L.). Bangladesh J. Pl. Breed. Genet. 23(1): 45-49. 